\title{
UNDERSTANDING THE MEANING OF GOD'S LEGISLATION: \\ Critical Analysis of Islamic Law Reasoning Criticism in Indonesia
}

\author{
Ipandang \\ Institut Agama Islam Negeri Kendari, Indonesia \\ Email: ipandangiainkendari@gmail.com
}

\section{Abstract}

The existence of Islamic law in dealing with social problems is questioned. The authoritative claim on the establishment of Islamic law by certain ulama organization is presumed to weaken the role of Islamic law in society. This article aims to analyze the legal reasoning structure and interpretation model of mufti (the one issuing fatwa) in establishing Islamic law. This article is based on the doctrinal legal research with conceptual approach, particularly on the thought of Khaled M. Abou El Fadl. By going through the analysis process of critical negotiation, there will be constructive dialectic to produce a humanistic Islamic law. This article found that the authority of textual meaning needs to be placed on top of the authority of mufti. The structured legal reasoning will silence the tafsir plurality on religious texts. The stagnation of this fatwa can be bridged via open Hermeneutics method which is dialectic among the author, text, reader, and the target discourse. So, fatwa can be the fundamental solution of the social problem which is humanistic.

Eksistensi hukum Islam dalam menangani masalah sosial kemasyarakatan mulai diragukan. Klaim otoritas penetapan hukum Islam oleh organisasi ulama tertentu disinyalir menjadi sebab melemahnya peran bukum Islam dalam masyarakat. Artikel ini bertujuan menganalisis struktur nalar bukum dan model interpretasi pemberi fatwa dalam penetapan bukum Islam. artikel ini berasal dari penelitian bukum doctrinal dengan konseptual khususnya pemikiran Khaled M. Abou El Fadl. Karena melalui proses analisis negosiasi kritis, akan muncul dialektika yang konstruktif untuk menghasilkan hukum Islam yang humanis. Artikel inimenemukan bahwa otoritas makna teks perlu diposisikan di atas kewenangan pemberi fatwa. 
Penalaran hukum yang terlembaga akan mendorong pembungkaman pluralitas tafsir teks agama. Kebekuan hasil fatwa ini dapat dijembatani melalui metode hermeneutika terbuka yang bersifat dialektis, antara pengarang, teks, pembaca, dan sasaran wacana. Sehingga fatwa dapat menjadi sandaran penyelesaian problem sosial kemasyarakatan yang humanis.

Keywords: fatwa, Islamic law, law hermeneutics.

\section{Introduction}

This article examines the existence of Islamic law in a society where, its role in dealing with socio-community problems began to be doubted. This doubt arises because the premises underlying Islamic law's emergence have been swallowed up by the legal fatwa-giving community. These subjects, fatwa giving community, assume themselves as God's representatives or even exceed God's authority. ${ }^{1}$ They then feel entitled to select and eliminate various legal products born from other sources. They even expressly "order" (the people) to carry out the legal products as God wills. There has been a shift in the authoritative pattern of the fatwa's (Islamic legal opinion) emergence at the moment. As concluded by Muhaimin's research that various authorities after prophetic treatises are necessity. These various authorities are socialized using different ways than before. ${ }^{2}$ However, there are external aspects influencing these legal products, until they reach the authoritative degree; ${ }^{3}$ namely the fatwas issued by the Indonesian Ulama Council (known as Majelis Ulama' Indonesia (MUI)).

Indeed, it needs to be recognized that Islamic law's stipulation can provide a solution to the socio-community problems within the frame of religious values. However, it will raise issues if the binding law causes anxiety (in the community) or even denies the existence of other authorities' legal products. Therefore, the authoritarian practice of Islamic law as misguided fatwas of the Ahmadiyah sect, prohibition understanding of Shia, and prohibition for Muslims to have pluralism, secularism, and liberalism concepts will result in the act of castrating God's authority and will tightly lock tightly on normative religious texts. This is why an authoritarian Islamic law emerged and is separated from God's "pure intentions." As in Habudin's research, el Fadl tends to use negotiated Hermeneutics

1 Kadi, "Menjadi Wakil Tuhan: Memahami Pemikiran Khalid M. Abou El Fadl Tentang Konsep Otoritas Penafsir Pesan Tuhan," Al-Abkam: Jurnal Hukum Dan Pranata Sosial, Vol. 7, No. 1, (2012): 1-16.

2 Muhaimin, "Pergeseran Otoritas Hukum Islam Perspektif Fenomenologi," Madania: Jurnal Kajian Keislaman 22, No. 1, (2018): 99-112.

3 Mohammad Syifa Amin Widigdo and Homaidi Hamid, "The Power of Fatwa in Indonesia: An Analysis of MUI's Controversial Fatwas," Jurnal Afkaruna 14, No. 2, (2018): 146-165. 
in understanding religious texts and ways of understanding Islamic law. ${ }^{4}$ The reason for the emergence of the authoritarian fatwa, as concluded in Raisul's research, was due to methodological errors. ${ }^{5}$

The correct and comprehensive use of Hermeneutics will actually make Islamic law give rise to a dialectical response to the times and developments. If this is constructed, then it will enrich the treasury of Islamic law to address socialcommunity problems. However in reality, the use of Hermeneutics has limited the God's role and "imprisoned the sacred purposes" in the text; (just) like the discourse about women (that somehow) has become something that castrated the existence of women themselves. The products of Islamic law born from an authoritarian community's thoughts have a very massive, dangerous impact. As Ghofur \& Sulistiyono describe that there is a change in the legal paradigm from classical Islamic law based on individual ijtihad to be based on national parliamentary legislation that necessitates the relevance of the decision of political/parliamentary authority as a manifestation of ijtihad's new definitive meaning. ${ }^{6}$

This phenomenon can disturb the Islamic community systemically, massively and thoroughly, because this community does not have the freedom to think, argue, or even practice their religious beliefs. Moreover, the social reality of the Islamic community is very plural and constantly changing. Therefore, this transformation continues to be aligned with the rhythm of the community's social spirit, but still based on the normative meta-ethical framework of Islamic religious texts. Nevertheless, Islamic law unfortunately has lost its epistemological base, which is very rich, and it is also trapped in the stagnation of the blind taqlid though the dynamics of Islamic law are thicker (more complete and thorough) in solving social problems; ${ }^{7}$ and all of the products (of Islamic law) retain a divine moral, ethical dimension. Al-Attar says that moral understanding in Islamic law needs to be harmonized with the "divine command" contained in al-maqashid al-shariah. ${ }^{8}$

The implication of the epistemological base loss is very massive and systemic to community growth and development. One of them is the castration of women's

4 Ihab Habudin, "Konstruksi Gagasan Feminisme Islam Khaled M. Abou El Fadl: Relevansinya Dengan Posisi Perempuan Dalam Keluarga,” Al-Abwal: Jurnal Hukum Keluarga Islam 5, No. 2, (2012): 1-30.

5 Raisul, "Pemikiran Hukum Islam Khaled Abou El Fadl," Mazabib: Jurnal Pemikiran Islam 14, No. 2, (2015), 145-158.

6 Abdul Ghafoor and Sulistiyono, "Peran Ulama Dalam Legislasi Modern Hukum Islam," Asy-Sir'ah: Jurnal Ilmu Syari'ah Dan Hukum 49, No. 1, (2014): 225-237.

7 Winarno, "Dinamisasi Hukum Islam: Suatu Pendekatan Dalam Kerangka Metodologi Ushul Fiqh," Nurani: Jurnal Kajian Syari'ah Dan Masyarakat 16, No. 1, (2016): 99-116.

8 Mariam al-Attar, "Meta-Ethics: A Quest for an Epistemological Basis of Morality in Classical Islamic Thought," Journal of Islamic Ethics 1, No. 1-2, (2017),:29-50. 
existence in the Islamic community; or religious fatwas against minority groups ${ }^{9}$ such as Syiah in Indonesia. ${ }^{10}$ Based on this context, Islamic scholars/academicians who try to offer methodological concepts emerge, one of which is El Fadl, who attempts to decipher two problematic aspects; first, the interpretation theory of the fatwa-giving community which places themselves as the authority owner over the authenticity of God's message; and second, the discourse of Islamic law from the products of the fatwa-giving community which is lame and dehumanized, such as legal products that discredit the position of women in the contemporary world. ${ }^{11}$ Based on this construction, Islamic law's discourse should develop to accompany and provide protection for the Islamic community based on human values. The dynamics of Islamic law will be able to answer the social problems that continue to emerge. Therefore, in this context, the author tries to analyze the frozenness of Islamic law caused by authoritarian reasoning in interpreting God's will.

\section{Research Methods}

This article focuses on a critical reading of the authoritarian reasoning structure based on the interpretation of the mufti (fatwa giver) as MUI. This critical study appears to find new conceptual ideas in Islamic law as a form of constructive offer. This construction remains binding and refers to persuasive and moral authority, not an authority in the fatwa-giving community. This is to bring back the epistemological foundation of the Islamic law that has been lost due to the reign of Islamic law reasoning from the mufti. Therefore, this article uses a qualitative approach to parse authoritarian Islamic law reasoning through literature review. So, the process of understanding the reasoning of the law will be deeper in order to bring up the Islamic law, meaning construction, which is egalitarian and humanist. For the data, the analysis instrument used to parse more details of the reasoning structure, the researcher used Islamic law reasoning criticism by Khaled M. Abou El Fadl. Through El-Fadl's critical negotiating analysis process -among the text, the observer, and the reader- a constructive dialectic will occur to produce Islamic law.

9 Idi Warsah, "Muslim Minority in Yogyakarta: Between Social Relationship and Religious Motivation," QIJIS: Qudus International of Islamic Studies 7, No. 2, (2019): 367-398.

10 Mukhsin Achmad, "A Hermeneutical Analysis on Fatwa of The Coucil of Indonesia Ulama Dealing with Discriminating Shia in Indonesia," Madania: Jurnal Kajian Islam 23, No. 1, (2019): 33-46.

11 Khaled M. Abou El Fadl, Atas Nama Tuhan: Dari Fiqh Otoriter Ke Fiqh Otoritatif, ed. R. Cecep Lukman Yasin (Jakarta: Serambi, 2004), 20. 


\section{Authority as a Problem: Coercive vs. Persuasive}

Indeed, to facilitate the critical analytical study of Islamic law, we need to have methodological instruments. These instruments can later be used to explain and bring up other concept offers. In this context, the researcher used Khaled M. Abou El Fadl's mindset as the methodological basis of analysis, namely the concept of normative-analytical thinking methods and the hermeneutics approach based on critical negotiations between text, author, and reader. Methodological instruments will lead to a systematic and comprehensive assessment. Conversely, Islamic law reasoning studies that do not use methodological instruments may potentially encounter difficulties when trying to find the root causes of problems as well as when trying to offer concepts that are solvable to the problems of Islamic law.

To unravel the problematic Islamic law reasoning, we need to come into the dialogical space among the text, the author, and the reader. The problem is, there are still many reviewers of Islamic law products, come into the reader room and claim to represent the author or initiator authority. The construction of inter and multi-disciplinary thinking cannot be detached/neglected as an alternative method of interpretation in Islamic law discourse. Even more so at this time, Islamic law often deals directly with various life problems, especially related to the issues of science and technology that are developing. Therefore, it is only natural that Nakissa, in her research states, there is an epistemological shift in Islamic law caused by religious learning based on language text to natural sciences model. ${ }^{12}$ This indicates that there is a dynamic pattern that is inherent in Islamic law. However, when Islamic law metamorphoses towards authoritarian law, then there is a faulty/ mishap that needs to be dismantled and addressed, especially for the mufti.

In this context, in dismantling the reasoning structure and interpreting the methods of the fatwa-giving community, scholars/academicians from several circles put forward various theories. One of them is El Fadl, who uses authority theory, associated with Friedman. ${ }^{13}$ In his view, there are two types of authority. The first is coercive authority i.e. the authority which relies on a particular structural position of a person or community. One is obeyed because of their position, so obedience to him/her is not based on the awareness of his/her personality. This means one's obedience arises based on the effect of social status or position, and is not based on the awareness of the capacity, potential, and personality consistency of the authority him/herself. The second, persuasive authority, that is an authority which is obeyed based on personal capacity motives. That is the obedience which

12 Aria Nakissa, "An Epistemic Shift in Islamic Law: Educational Reform at Al-Azhar and Dar AlUlum," Islamic Law and Society 21, No. 3, (2014): 209-221.

13 Khaled M. Abou El Fadl, Atas Nama Tuhan: Dari Fiqh Otoriter Ke Fiqh Otoritatif. 
arises based on self-awareness of the capacity, potential, and consistency of one's personality so that this obedience is not blind to reality. This authority arises from the expertise, skills, and/or from the charisma inherent to a person, so obedience that is resulted is based on recognition and awareness, not from the pressure that is structural-normative.

These two authorities actually have different characteristics, so they can incarnate in one or different subject. For example, in the early days of Islamic growth, the Quraysy figures, family, and close friends of the Prophet Muhammad PBUH, became the people who were considered to receive authority after the death of the Prophet. They were followed and obeyed based on the awareness that they were considered to have the capacity, potential, and personality like the Prophet. However, since the birth of the legal professionals (fuqaha') after their era, that persuasive authority was distributed. Moreover, the development of jurisprudence books and technical culture of law with specific language, symbols, and structures placed fuqaha' as a representative of an established institution. In this context, since the $4^{\text {th }}$ century AH, the Prophet Muhammad's authority was manifested firmly in the concept of Islamic law and its guardians, the fuqaba. ${ }^{14}$

Therefore, the two authorities work dynamically until the time comes to manifest with its final form. Therefore, it is stated that there needs to be an effort to raise the awareness of Muslim so that they do not think that the perfection of religion can be realized when it is related to the state affairs. ${ }^{15}$ This means that the transformation of persuasion to coercive authority is very likely to shift and occur. Even more so, if communities that have special charisma or expertise place themselves as the sole authoritative reader. They even eliminate other parties who may also have the same authority. On this platform, the persuasive authority of the fatwa-giving community has turned to coercive authority. This authority's attitude and pattern, according to El Fadl, will lead to the emergence of authoritarianism, which is hegemonic to all layers of $i j t i h a d$ independence. For instance, there are people who tend to glorify their own aspects of methodology and interpretation and read legal products than those of others so that they will be as exclusive and arrogant as the attitude of fundamentalism. ${ }^{16}$

14 Kadi, Menjadi Wakil Tuhan, 1-16.

15 Rumadi, "Islam Dan Otoritas Keagamaan," Walisongo: Jurnal Penelitian Sosial Keagamaan 20, No. 1, (2012),:25-54.

16 Neli Rahmah \& Nelmaya, "Islamic Fundamentalism Karen Amstrong's Perspective and Its Implications for the Identification of Fundamentalism Groups in Indonesia," Realitas: Journal of Islamic \& Social Studies 5, No. 2, (2019): 217-229. 
Therefore, there needs to be openness of reasoning to foster self-awareness as revealed by El Fadl as "exclusive reasoning"; this is used to avoid authoritarianism. ${ }^{17}$ With this reasoning, people have a wide range to consider the product (fatwa) of the Islamic law from the fatwa-giving community. If one follows without making free choices through exclusive reasoning, then, in fact, he/she has fostered an attitude of authoritarianism. The researcher in this aspect tends to refer to the closed cult attitude towards certain authorities. In this attitude, it will place oneself or the fatwa-giving community of Islamic law to be authoritarian, which eventually will be hegemonic to all layers of social-community. This is like mainstream Islam when reconstructing the meaning of pluralism through fatwas issued by formal institutions which, in fact, clearly has an impact on Islamic law. ${ }^{18}$

In this position, sacred religious texts occupy a central role in unraveling the problems flow. Because the text is a normative foothold of interpretation in exploring Islamic law, the text can be placed as an open entity to review. Even Johnston states, the step of epistemological objectivism of ethical values to the text will open up opportunities for the conservatism and progressivism's meeting. ${ }^{19}$ This context is very much realized by El Fadl, so he assumes that when a text is separated from the originator, it experiences semi-autonomy. ${ }^{20}$ Nevertheless, the initiator's basic message still exists in it; it does not mean that the text is autonomous, which imprisons the initiator's original intentions. Therefore, when God revealed message in the form of the Quran to Prophet Muhammad, then in this framework, we are obliged to explore the pure intentions of God through ijtihad based on persuasive authority by binding ourselves to moral values.

\section{Sharia and Islamic Law: A Hermeneutics Analysis}

Based on this framework, we need to critically and systematically unravel the problem of interpretation methods or Hermeneutics used by the fatwagiving community. This is important to be put forward as a critical study base of authoritarian problems in the dynamics of Islamic law. On the other hand, El Fadl himself also analyzed the problem using the basis of Hermeneutics, so that the root of problems from the basis of Islamic law namely, normative religious texts could be revealed. This condition was carried out by Duderija when he was doing

17 Khaled M. Abou El Fadl, Atas Nama Tuhan: Dari Fiqh Otoriter Ke Fiqh Otoritatif.

18 Syafiq Hasyim, "Religious Pluralism Revisited: Discursive Patterns of the Ulama Fatwa in Indonesia and Malaysia," Studia Islamika 26, No. 3, (2019): 475-509.

19 David L. Johnston, "Maqasid Al-Shari'a: Epistemology and Hermeneutics of Muslim Theologies of Human Rights," International Journal for the Study of Modern Islam 47, No. 2, (2007): 149-187.

20 Khaled M. Abou El Fadl, Atas Nama Tuhan: Dari Fiqh Otoriter Ke Fiqh Otoritatif. 
his research on the Hermeneutics of the scriptures about Islamic feminism. He tried to dismantle the mechanism of Hermeneutics works of the Muslim's holy book about the concept and purpose of feminism. ${ }^{21}$

From this methodology, a conceptual offer will be raised as a logical implication of the critical study results. Because the root of the problem lies in two large slices, namely the author and the text; the Hermeneutics method will be used as the basis for the concept offers as well. Each of the slices is described as follows:

\section{Author-oriented Hermeneutics: the Frozen Dimensions}

Essentially, Hermeneutics is the science and art of text interpretation that is widely used to answer social dynamics of diversity such as Islamic extremism; ${ }^{22}$ to draw wisdom from the history of humanity $;^{23}$ or to explore the values of science. ${ }^{24}$ However, the main problem lies in the search for text's meaning, namely objective or subjective meaning. This is to issue and understand the "God's pure intentions" contained in religious texts. It is common to determine the text's meaning in three variants i.e. the author (the world of the author), the text (the world of text), and the reader (the world of the reader). ${ }^{25}$ These three variants are often separated in deciphering the text in order to understand the author's intentions, or also tend to be related to find the construction of reality as Dorroll did in understanding the modern religious thought of Turkish society. ${ }^{26}$ There nonetheless needs to be an affirmation between the phenomenology itself and the Hermeneutics phenomenology and that any differences and similarities need to be emphasized, as explained in Laverty's research. ${ }^{27}$

21 Adis Duderija, "Toward a Scriptural Hermeneutics of Islamic Feminism," Journal of Feminist Studies in Religion 31, No. 2, (2015): 45-64.

22 Norman K. Swazo, "Engaging the Hermeneutics of Suspicion about Islamic Faith and Practice," International Journal on World Peace 33, No. 2, (2016): 9-41.

23 Dadang Darmawan, "Analisa Kisah Yusuf Dalam Al-Qur'an Dengan Pendekatan Hermeneutika," Dalam Al-Bayan: Jurnal Studi Al-Qur'an Dan Tafsir 1, No. 1, (2016): 8-16.

24 Melanie Guenon, "Abd Al-Majid Al-Zindani I'jaz 'Ilmi Approach: Embryonic Development in Q. 23: 12-14 as a Scientific Miracle," Journal of Qur'anic Studies 21, No. 3, (2019): 32-56.

25 Khaled M. Abou El Fadl, Atas Nama Tuhan: Dari Fiqh Otoriter Ke Fiqh Otoritatif.

26 Phillip Dorroll, "The Turkish Understanding of Religion": Rethinking Tradition and Modernity in Contemporary Turkish Islamic Thought," Journal of the American Academy of Religion 82, No. 4, (2014): 1033-1069.

27 Susann M. Laverty, "Hermeneutic Phenomenology and Phenomenology: A Comparison of Historical and Methodological Considerations," International Journal of Qualitative Methods 2, No. 3, (2003): $21-35$. 
Therefore, Hermeneutics is always used by mufti to construct Islamic law (fatwas) from religious texts. They tend to embrace romantic Hermeneutics, which is oriented towards the search for objective meaning. They even place and consider God's position as the absolute authority holder. It is as if they are (the mufti) the legitimate representative of the authenticity holder of God's message that they forget their own relativity. Their assumption is that Islamic law is considered as an organic and coherent system in which there is a systematic relationship between methodology (usual) and legal substance (furu'), even more tragic, when the application of the law is often separated from the methodology as a transformational way of Islamic law. Therefore, Ibrahim, in his research, critically states that these dynamics bring up an apathetic attitude towards methodological framework without pursuing law flexibility. ${ }^{28}$

Based on this framework, in fact, the mufti should parse and present God's "pure intentions" in the text objectively, without any tendency. Romantic Hermeneutics itself realizes that understanding the text lies in the search for the meaning essence desired by the author objectively. This form of interpretation assumes that a reader needs to and must equate his/her position with the text author. Although at the same time, this pattern will undermine the language authority as a medium and determinant of meaning. ${ }^{29}$ In this position, the reader also acts as if he/she is the shadow of the author; readers or interpreters of religious texts can be depicted as "representatives" of God. Therefore, in the Islamic law context, assumptions like this eventually make the reader's understanding of the text is seen as the right attitude and is representing the author's intention. Conversely, if a reader's understanding is different from another, that is, a reader who positions him/herself as the text author, it means that there has been an error in the author's intention. Thus, a reduction and manipulation of God's "pure intentions" must have happened.

The logic of this interpretation has very serious implications -it can be said as dangerous- for Muslim when facing various socio-community problems because in their hands, this Hermeneutics has the opportunity to metamorphose to another more extreme form, namely authoritarian Hermeneutics. In this context, the fatwa of Islamic law, when institutionalized, led to the silencing of the interpretations plurality of religious texts. Therefore, there is only one interpretation, and outside

28 Ahmed Fekry Ibrahim, "The Codification Episteme in Islamic Juristic Discourse between Inertia and Change," Islamic Law and Society 22, No. 3, (2015): 157-220.

29 Muhammad 'Ata al-Sid, Sejarah Kalam Tuhan: Kaum Beriman Menalar Al-Qur'an Masa Nabi, Klasik, \& Modern, ed. Ilham B. Saenong (Jakarta: Teraju, 2004). 
the official interpretation, it is impossible to come up with other interpretations. It is said so because the texts that were studied and understood will be claimed as authentic messages of God. The results of understanding are considered sacred and must be carried out by the community of God's servants. Whereas the approach to the texts is very diverse, including from the linguistic and literary dimensions, as reviewed by Naguib in his research ${ }^{30}$ and it continues to evolve continuously, as pointed out in Saeed's research study. ${ }^{31}$

Based on these aspects, the fatwa-giving community will dominate the plurality framework of other interpreting authorities. There are at least three definite implications. First, the fatwa-giving community will castrate the authority of the text author even though God wants all readers (human) make an effort to interpret God's will seriously. This effort in fiqh terminology is called ijtihad, but in El Fadl's perspective, this suggestion is a form of eliminating authoritarianism's attitude. ${ }^{32}$ Moreover, it will give every reader the freedom to try as much as possible to find the "pure intentions" of God. Moreover, as Hidayat said, religious texts will be meaningful when it is positioned relational to the reading community. ${ }^{33}$ That is, religious texts are very open to being interpreted by anyone who has the potential or the authority to emerge a diversity of interpretations in society.

Second, the dominative authority of the fatwa's community goes beyond the text authority as a fixation of God's will and purpose in written form. This claim interpretation (tafsir) arises from their attitude as interpretations that represent the author's position. Finally, the understanding that was born from the results of others interpretations is wrong and their validity is not cognizable. This means the mufti has restricted the text's authority and made it closed and static. The religious text is open, active, and dynamic, even it is constantly negotiable based on its context. Therefore, the text will experience relative autonomy and has an objective reality that is beyond the control of the author or reader. Although the text does not represent God's message and intentions correctly, it will provide extensive opportunities for various interpretations from its reader. The Quran text is consistent with several different interpretations, giving rise to the view that

30 , Shuruq Naguib, "The Hermeneutics of Miracle: Evolution, Eloquence, and the Critique of Scientific Exegesis in the Literary School of Tafsir. Part I: From Muhammad 'Abduh to Amin Al-Khuli," Journal of Qur'anic Studies 21, No. 3, (2019): 57-88.

31 Sohaib Saeed, "The Shahin Affair and the Evolution of Usul Al-Tafsir," Journal of Qur'anic Studies 21, no. 3 (2019): 114-144.

32 Khaled M. Abou El Fadl, Atas Nama Tuhan: Dari Figh Otoriter Ke Fiqh Otoritatif.

33 Komaruddin Hidayat, Memahami Bahasa Agama: Sebuab Kajian Hermeneutike (Jakarta: Paramadina, 1996). 
there is plurality of Islamic religiosity forms that are equally valid..$^{34}$

If the dominative attitude is realized, then at the same time, the fatwa-giving community has denied the existence of elements that have changed in Islam or the Quran. Instead, this attitude has placed the text as a whole in a fixed element; and the only fixed position (static) is their fatwa. This is the third implication that manifests on the surface. In turn, an understanding of other interpretations community that differ from those of the understanding of the Quran -the product of Islamic law- tends to be seen as incompatible with God's will. In this context, Hermeneutics' main task is to investigate texts to uncover religious meaning (literary criticism)..$^{35}$ If this paradigmatic is used, then all understanding of text interpretation will be relative and tend to change.

Based on the three implications, it is evident if the fatwa-giving community cannot distinguish between shar'i (normative) and historical parts. Shar'i is static and does not change, while history is dynamic and will continue to change. They have exceeded God's authority so that they seem arrogant by limiting the God's role and the autonomy of religious texts. Therefore, in Indonesia, the term "Islam Nusantara" is a process of assimilation and acculturation of "authentic Islam" with the Indonesian culture, although, this term was rejected by scholars as in West Sumatra. ${ }^{36}$

\section{Text-Oriented Hermeneutics: the Static and Dynamic Elements}

As an instrument of criticism, Hermeneutics needs to be used on texts based on moral zeal, honesty, commitment, holistic, self-control, and rationality. Although these conditions are not deterministic, they are very substantive to produce the text's objective meaning. Therefore, it is integrated into the operationalization of Hermeneutics, especially in Phenomenological Hermeneutics. This Hermeneutics negotiates the thoughts of the author, the text, and the reader by making the text as the open central point. When pure thoughts and intentions are separated from the author (or initiator) and imprisoned in the text, the text experiences Autonomization because it no longer refers to the author's subject. There are at least three sets of autonomy in the text; those are autonomy from the author, from the original

34 Victoria S. Harrison, "Hermeneutics, Religious Language and The Qur'an," Islam and Christian-Muslim Relation 21, No. 3, (2010): 207-220.

35 Ayman A. El-Desouky, "Between Hermeneutic Provenance and Textuality: The Qur'an and the Question of Method in Approaches to World Literature," Journal of Qur'anic Studies 16, No. 3, (2014): $11-38$.

36 Benny Ridwan and et al., "Islam Nusantara, Ulemas, and Social Media: Understanding the Pros and Cons of Islam Nusantara among Ulemas of West Sumatera," Indonesian Journal of Islam and Muslim Societies 9, No. 2, (2019): 163-188. 
meaning, and from the initial audience. These three autonomies are:interrelated. Even so, the staging message is still stored in the text, so the message can be traced through readings that are negotiating between the reader and the text.

Besides, there are facts that need to be realized by the mufti, namely the awareness of failure to reveal the text's meaning. In his research, Davey explained, the Hermeneutics failure dimension is very dependent on different perspectives so that the meaning appearing on the surface will replace the previous understanding. ${ }^{37}$ As such, there are spaces of error created by the authority of mufti that need to be realized from the outset. This means a single interpretation of the text-only encourages the emergence of community's forced understanding. On this basis, it is necessary to have an effort of emancipatory and egalitarian movements on the basis of humanity in the text interpretation. Therefore, when unraveled contemporary phenomena, it was based on anxiety over the debate between Transhumanism and Posthumanism in the $20^{\text {th }}$ century thought to be anti-humanism. ${ }^{38}$

For this reason, efforts are needed to strike the fatwa-giving community position with its authoritarian actions. An offer in this context is to restore the authority of the text meaning above the reader's authority, as the call of romantic Hermeneutics. This kind of Hermeneutics, in turn, leads people to find fixed (static) and changing (dynamic) elements in Islam. The constant element is God's universal human message, which exists in the text. It is in the process of finding a reading community through the door of $i j t i h a d$. This universal human message is sharia. Another term used by M. Amien Abdullah in the book "Religious Studies" is normativity. ${ }^{39}$ This element occupies a usual position and normative in Islam so that it forever will not undergo an essential transformation. At the same time, the element that is always changing (dynamic) is the understanding of sharia, commonly called Islamic law. The second element is transforming the social reality. Moreover, the text concept is indeed open to various interpretations. ${ }^{40}$ Therefore, it can be said that this second element is a branch in Islam, which often correlates and intersects with the historical value of humanity.

37 Nicholas Davey, "The (Impossible) Future of Hermeneutics," Journal of the British Society for Phenomenology 48, No. 3, (2017): 209-221.

38 Cristian Iftode, "The Dispute between Humanism and Anti-Humanism in the 20th Century: Toward an Archeology of Posthumanism," Hermeneia: Journal of Hermeneutics, Art Theory and Art Criticism 1, No. 1, (2020): 6-16.

39 M. Amin Abdullah, Studi Agama: Normativitas Dan Historisitas (Yogyakarta: Pustaka Pelajar, 2004), 25.

40 Khaled M. Abou El Fadl, Atas Nama Tuhan: Dari Fiqh Otoriter Ke Fiqh Otoritatif. 


\section{Subjective-Liberative Hermeneutics}

Based on this analytical description, it is necessary to have radical breakthroughs to get out of the authoritarian circle and shackle coercive authority. Therefore, we need to criticize the fatwa of Islamic law, so that a mufassir (commentator) does not make arbitrary decision in interpreting the text of the Quran. ${ }^{41}$ One realistic effort is through massive movements to shift romantic into phenomenological Hermeneutics. However, what needs to be underlined is that there is a room that is "unthinkable" by this Hermeneutics methodology. It wants to provide a broad range for all readers, but without realizing it, it has eliminated the existence and role of the Islamic law texts' discourse meaning target. It always focuses on the reader, so it is constantly negotiating between the text and the reader. Whereas the desired discourse in text interpretation is not only for the reader, but there are definitely others whose intellectual quality or knowledge is different from the reader.

Finally, it cannot be denied if the discourse target cannot be separated from the framework basic of the text meaning, and it needs to base on solid principles. One principle that must exist in this context, as Cheng said, is comprehensive observation and inter-subjectivity. ${ }^{42}$ Both principles will put the text interpretation neutrally or proportionally, without interfering of personal or group interests. The most appropriate example is the meaning of jihad. As cited by Romadlan, Muhammadiyah interprets it as "the struggle to overcome challenges by creating a superior movement", which contrasts with the meaning believed by terrorists. ${ }^{43}$ Another example is on the discussion of QS. Al-Baqarah [2]: 185 concerning hilal. The verse states that the acceptable hilal witness is specific to people who have sufficient expertise and ability in the process of rukyat al-bilal. This is different from the interpretation of most scholars like Quraish Shihab, Ibn Kathir, al-Razi, and so forth. ${ }^{44}$

A comprehensive and inter-subjective interpretation of the text will bring a humanist and egalitarian interpretation, and develop persuasive authority over the reader. Especially when considering the target of discourse as the primary reference, it will strengthen the aspects of trust and positive image and foster

41 Adang Kuswaya and MK. Ridwan, "Mentradisikan Kritik Tafsir: Upaya Meretas Mata Rantai Absolutisme Penafsiran,” Episteme: Jurnal Pengembangan Ilmu Keislaman 13, No. 1, (2018): 1-31.

42 Chung-Ying Cheng, "Phenomenology and Onto-Generative Hermeneutics: Convergencies," Journal of Chinese Pbilosopby 42, No. 1-2, (2017): 221-241.

43 Said Romadlan, "The Discourse of Meaning of Jihad in Muhammadiyah Circle: A Hermeneutics Perspective," Jurnal Komunikator 11, No. 2, (2019): 151-162.

44 Muhammad Nurkhanif, "Hermeneutics and Deconstruction of Hilal Testimony Verse: Critical View on QS. Al-Baqarah 185," Dalam Ulul Albab: Jurnal Studi Islam 21, No. 1, (2020): 67-85. 
social welfare. This can occur due to the focus, direction, and pattern of meaning following the ability of reasoning to discourse target. Even on the one hand, it will minimize the reader's subjectivity and maximize the neutrality. Because the authors believe, no interpretation can be separated from the personal influence of the reader and eliminate the influence of prior text from its interpretation. For this reason, there is no utterly objective method of interpreting the Quran because each interpretation makes several subjective choices. Likewise, there are no definite and static interpretations so that every text interpretation can contain "errors" and "negligence".

Based on this framework, involving the target subjects in the meaning is a form of necessity to create a humanist and participatory Islamic legal reasoning. It means, in addition to the meaning adjusted to the target subject of discourse, the fatwa-giving community as a reader definitely has other meanings that are specific to him and his qualified community. Therefore, the researcher emphasizes that there needs to be an effort to look for other Hermeneutics patterns that consider the target of Islamic legal discourse and produce concrete actions that are capable of "liberating." In this context, the researcher's offer is a reading method using subjective-liberation hermeneutic patterns. This Hermeneutics has a pioneer based on the mainstream of thought of Hans-George Gadamer, Jacques Derrida, Farid Esack, and also Hasan Hanafi.

Unlike the contemporary Hermeneutics, subjective-liberative Hermeneutics act of reading, not only considering the author, the text, and the reader, but also the discourse subject. However, it is not only produced theoretical discourse, but it has a final goal, namely concrete liberating and solvable actions on social problems. Therefore, this Hermeneutics will be one of the efforts to release Islamic law from social structures, politics, and religious systems that demand absolute obedience (coercive authority). Religion (Islamic law) will be a source of awareness, ethical basis (moral), and a reference to values and procedures for community life. Through this final construction, the discourse target will have a theocentric worldview that directs them in the existential evolutionary movement to become a theomorphic man, that is, humans with characteristics of divine attributes, as Shari'ati's idealism. ${ }^{45}$ This also gave rise to humanist actions in the religious ummah and eliminated the attitude of religious arrogance, which is only oriented towards spiritual values. ${ }^{46}$ Although on the other hand, Jati's research found that arrogance

45 Syamsul Rijal Adhan, "Theology of Liberation in Thought of Ali Shari'ati," Journal of Islam and Science 3, No. 2, (2016): 259-288.

46 Syamsul Rijal and et al., "Religion, Theology, and Terrorism in Indonesia: Reconstruction of TheoAnthropocentric Theology," International Journal of Philosopby and Theology 5, No. 1, (2017): 36-46. 
or radicalism arises from the spirit of freeing Muslims from economic inequality and political marginalization. ${ }^{47}$

Thus, Hermeneutics offers the concept of five-legged circle, namely the author, the text, the reader, the target of discourse, and the final estuary. These five elements are subjective-liberative, which continuously emerge to the dialectical text meaning between the author, the reader, and the target of discourse. To find that meaning as well when negotiated with the author, the text remains bound to the awareness of God and humanity so that the reader and the discourse target remain within the ethical framework of the Islamic religion. In turn, it will make the meaning of a double-faced text. If it is related to the scholar reader, the text has scientific meaning. However, if it is associated with the laity or common people, the text will have different meanings. Based on these conditions, there needs to be a framing text that has a color of compatibility between all readers, even though it is unlikely to be realized.

Such conditions create balance and dialectics in understanding and interpreting texts openly. The coercive authority of the fatwa provider will find it challenging to grow and develop so that the dominant interpretation of religious texts is not institutionalized and impresses the closed text (closed ijtihad). Therefore, it is essential to compare the basic framework of romantic Hermeneutics that tends to be used by mufti with subjective-liberative Hermeneutics. The chart of the romantic Hermeneutics is as shown in the following image:

Figure 1. Romantic Hermeneutics

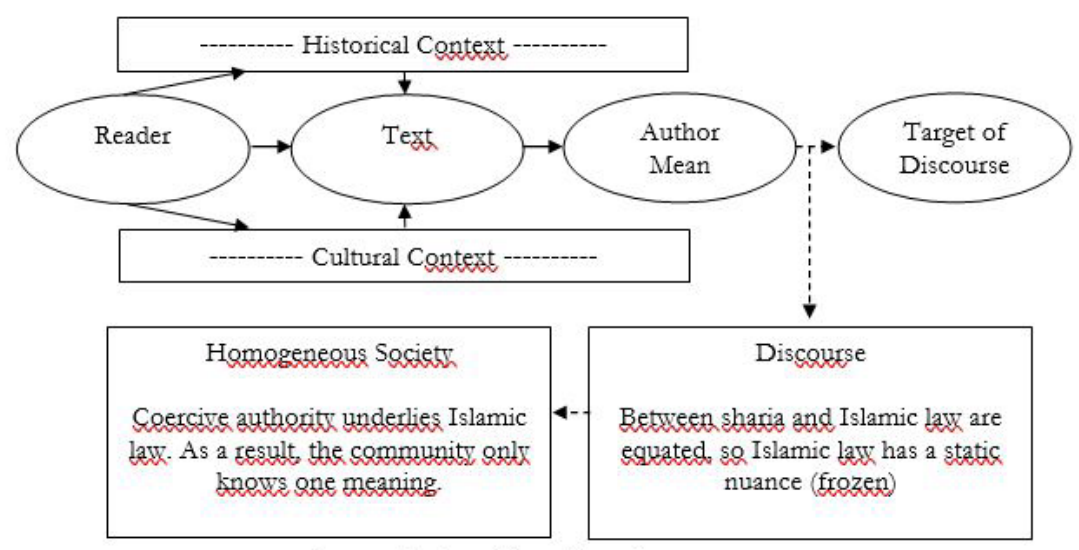

Source: Analyzed from the primary source

47 Wasisto Raharjo Jati, "Radicalism in the Perspective of Islamic-Populism: Trajectory of Political Islam in Indonesia," JOURNAL OF INDONESLAN ISLAM 7, No. 2, (2013): 268-87. 
Based on the chart, it can be read that the tradition of the interpretation of religious texts is still theocentric rather than anthropocentric. That is, the mufti talk more about texts correlated with the metaphysical nature of God rather than empirical reality. The target of dimensions discourse finally released and "as if" they were indeed not given space by the mufti. However, the mufti strongly rejects "the death of the author" principle; a principle held by many deconstructionists. While the chart of concepts offered by the author is as shown below:

Figure 2. Subjective-Liberative Hermeneutics Image

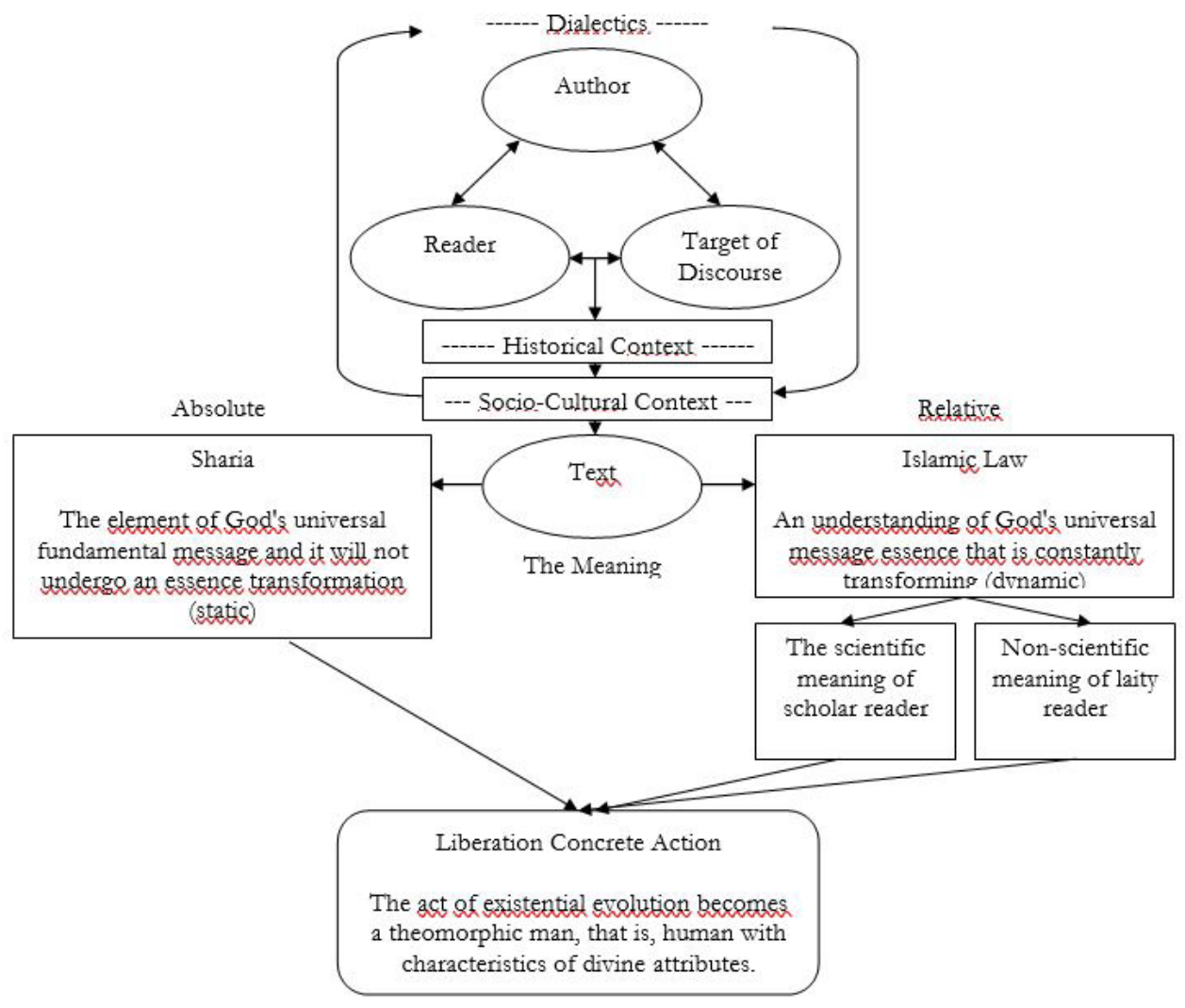

Source: Analyzed from the primary source

Based on the chart, clearly, the meaning of religious texts is relative (nondivine) and has a plurality of colors. However, all of that will lead to the act of enlightening a society that is decorated with spiritual values. From this pattern, Islamic law will never bring up coercive authority and open up dominationauthoritarian spaces for mufti. 


\section{Conclusion}

The reasoning of Islamic law, which is closed, is apparently able to foster and develop authoritarian dominative actions. Moreover, this institutionalized law reasoning will encourage the silencing of the interpretation plurality of religious texts. Therefore, opening the authoritarian "shackles" requires methodological efforts, one of which is by emerging the various texts meaning. This construction can only be done through open Hermeneutics with the dialectical nature between the author, the text, the reader, and the discourse target. However, the meaning of Islamic law texts must be translated in the form of liberative actions. In the end, it will not only be able to provide an understanding of humanist Islamic law but also enlighten the lives of the wider community.

\section{References}

Abou El Fadl, Khaled M. Atas Nama Tuhan: Dari Fiqh Otoriter Ke Fiqh Otoritatif. Edited by R. Cecep Lukman Yasin. Jakarta: Serambi, 2004.

Abdullah, M. Amin. Studi Agama: Normativitas Dan Historisitas. Yogyakarta: Pustaka Pelajar, 2004.

Al-Sid, Muhammad 'Ata. Sejarah Kalam Tuhan: Kaum Beriman Menalar Al-Qur'an Masa Nabi, Klasik, \& Modern. Edited by Ilham B. Saenong. Jakarta: Teraju, 2004.

Hidayat, Komaruddin. Memahami Bahasa Agama: Sebuah Kajian Hermeneutik. Jakarta: Paramadina, 1996.

Achmad, Mukhsin. "A Hermeneutical Analysis on Fatwa of The Coucil of Indonesia Ulama Dealing with DiscriminatingShia in Indonesia." Madania: Jurnal Kajian Islam 23, no. 1 (2019): 33-46.

Adhan, Syamsul Rijal. "Theology of Liberation in Thought of Ali Shariati." Journal of Islam and Science 3, no. 2 (2016): 259-88.

Al-Attar, Mariam. "Meta-Ethics: A Quest for an Epistemological Basis of Morality in Classical Islamic Thought." Journal of Islamic Ethics 1, no. 1-2 (2017): 29-50.

Cheng, Chung-Ying. "Phenomenology and Onto-Generative Hermeneutics: Convergencies." Journal of Chinese Philosophy 42, no. 1-2 (2017): 221-41. 
Darmawan, Dadang. "Analisa Kisah Yusuf Dalam Al-Qur'an Dengan Pendekatan Hermeneutika." Dalam Al-Bayan: Jurnal Studi Al-Qur'an Dan Tafsir 1, no. 1 (2016): 8-16.

Davey, Nicholas. "The (Impossible) Future of Hermeneutics." Journal of the British Society for Phenomenology 48, no. 3 (2017): 209-21.

Dorroll, Phillip. “The Turkish Understanding of Religion”: Rethinking Tradition and Modernity in Contemporary Turkish Islamic Thought." Journal of the American Academy of Religion 82, no. 4 (2014): 1033-69.

Duderija, Adis. "Toward a Scriptural Hermeneutics of Islamic Feminism." Journal of Feminist Studies in Religion 31, no. 2 (2015): 45-64.

El-Desouky, Ayman A.. "Between Hermeneutic Provenance and Textuality: The Qur'an and the Question of Method in Approaches to World Literature." Journal of Qur'anic Studies 16, no. 3 (2014): 11-38.

Ghofur, Abdul, and Sulistiyono. "Peran Ulama Dalam Legislasi Modern Hukum Islam." Asy-Syirah: Jurnal Ilmu Syariah Dan Hukum 49, no. 1 (2014): 225-97.

Guenon, Melanie. "Abd Al-Majid Al-Zindani I'jaz 'Ilmi Approach: Embryonic Development in Q. 23: 12-14 as a Scientific Miracle." Journal of Qur'anic Studies 21, no. 3 (2019): 32-56.

Habudin, Ihab. "Konstruksi Gagasan Feminisme Islam Khaled M. Abou El Fadl: Relevansinya Dengan Posisi Perempuan Dalam Keluarga." Al-Ahwal: Jurnal Hukum Keluarga Islam 5, no. 2 (2012): 1-30.

Hasyim, Syafiq. "Religious Pluralism Revisited: Discursive Patterns of the Ulama Fatwa in Indonesia and Malaysia." Studia Islamika 26, no. 3 (2019): 475-509.

Harrison, Victoria S. “Hermeneutics, Religious Language and The Qur'an." Islam and Christian-Muslim, Relation 21, no. 3 (2010): 207-20.

Ibrahim, Ahmed Fekry. "The Codification Episteme in Islamic Juristic Discourse between Inertia and Change." Islamic Law and Society 22, no. 3 (2015): 157-220.

Iftode, Cristian. "The Dispute between Humanism and Anti-Humanism in the 20th Century: Toward an Archeology of Posthumanism." Hermeneia: Journal of Hermeneutics, Art Theory, and Art Criticism 1, no. 1 (2020): 6-16. 
Jati, Wasisto Raharjo. "Radicalism in the Perspective of Islamic-Populism: Trajectory of Political Islam in Indonesia." Journal Of Indonesian Islam 7, no. 2 (2013): 268-87.

Johnston, David L. “Maqasid Al-Shari’a: Epistemology and Hermeneutics of Muslim Theologies of Human Rights." International Journal for the Study of Modern Islam 47, no. 2 (2007): 149-87.

Kadi. "Menjadi Wakil Tuhan: Memahami Pemikiran Khalid M. Abou El Fadl Tentang Konsep Otoritas Penafsir Pesan Tuhan." Al-Ihkam:Jurnal Hukum Dan Pranata Sosial 7, no. 1 (2012): 1-16.

Kuswaya, Adang, and MK. Ridwan. "Mentradisikan Kritik Tafsir: Upaya Meretas Mata Rantai Absolutisme Penafsiran." Episteme: Jurnal Pengembangan Ilmu Keislaman 13, no. 1 (2018): 1-31.

Laverty, Susann M. "Hermeneutic Phenomenology and Phenomenology: A Comparison of Historical and Methodological Considerations." International Journal of Qualitative Methods 2, no. 3 (2003): 21-35.

Muhaimin. "Pergeseran Otoritas Hukum Islam PerspektifFenomenologi." Madania: Jurnal Kajian Keislaman 22, no. 1 (2018): 99-112.

Naguib, Shuruq. “The Hermeneutics of Miracle: Evolution, Eloquence, and the Critique of Scientific Exegesis in the Literary School of Tafsir. Part I: From Muhammad 'Abduh to Amin Al-Khuli." Journal of Qur'anic Studies 21, no. 3 (2019): 57-88.

Nakissa, Aria. "An Epistemic Shift in Islamic Law: Educational Reform at Al-Azhar and Dar Al-Ulum." Islamic Law and Society 21, no. 3 (2014): 209-51.

Nurkhanif, Muhammad. "Hermeneutics and Deconstruction of Hilal Testimony Verse: Critical View on QS. Al-Baqarah 185.” Dalam Ulul Albab: Jurnal Studi Islam 21, no. 1 (2020): 67-85.

Rahma, Neli h \& Nelmaya. "Islamic Fundamentalism Karen Amstrong's Perspective and Its Implications for the Identification of Fundamentalism Groups in Indonesia." 
Realitas: Journal of Islamic \& Social Studies 5, no. 2 (2019): 217-29.

Raisul. "Pemikiran Hukum Islam Khaled Abou El Fadl." Mazabib: Jurnal Pemikiran Islam 14, no. 2 (2015): 145-58.

Ridwan, Benny, and et al. "Islam Nusantara, Ulemas, and Social Media: Understanding the Pros and Cons of Islam Nusantara among Ulemas of West Sumatera." Indonesian Journal of Islam and Muslim Societies 9, no. 2 (2019): 163-88.

Rijal, Syamsul, and et al. "Religion, Theology, and Terrorism in Indonesia: Reconstruction of Theo-Anthropocentric Theology." International Journal of Philosophy and Theology 5, no. 1 (2017): 36-46.

Romadlan, Said. "The Discourse of Meaning of Jihad in Muhammadiyah Circle: A Hermeneutics Perspective." Jurnal Komunikator 11, no. 2 (2019): 151-62.

Rumadi. “Islam Dan Otoritas Keagamaan.” Walisongo: Jurnal Penelitian Sosial Keagamaan 20, no. 1 (2012): 25-54.

Saeed, Sohaib. "The Shahin Affair and the Evolution of Usul Al-Tafsir." Journal of Quranic Studies 21, no. 3 (2019): 114-44.

Swazo, Norman K. "Engaging the Hermeneutics of Suspicion about Islamic Faith and Practice." International Journal on World Peace 33, no. 2 (2016): 9-41.

Warsah, Idi. "Muslim Minority in Yogyakarta: Between Social Relationship and Religious Motivation.” QIJIS: Qudus International of Islamic Studies 7, no. 2 (2019):367-98.

Widigdo, Mohammad Syifa Amin, and Homaidi Hamid. "The Power of Fatwa in Indonesia: An Analysis of MUI's Controversial Fatwas." Jurnal Afkaruna 14, no. 2 (2018): 146-65.

Winarno. "Dinamisasi Hukum Islam: Suatu Pendekatan Dalam Kerangka Metodologi Ushul Fiqh." Nurani:Jurnal Kajian Syariah Dan Masyarakat 16, no. 1 (2016): 99-116. 